\title{
DAMPAK PANDEMI COVID-19 TERHADAP PROSES PEMBELAJARAN SISWA TINGKAT SEKOLAH DASAR
}

\author{
Miptah Parid ${ }^{1}$, Julrissani2 \\ ${ }^{1,2}$ Program Magister Pendidikan Guru Madrasah Ibtidaiyah, UIN Sunan Kalijaga Yogyakarta \\ Email:paridmiptah24@gmail.com, julrissanij@gmail.com
}

\begin{tabular}{|c|c|}
\hline INFO AR & TIKEL \\
\hline \multicolumn{2}{|c|}{ Riwayat Artikel: } \\
\hline Menerima & : 18 September 2 \\
\hline Revisi & : 11 April 2021 \\
\hline Diterima & : 14 April 2021 \\
\hline
\end{tabular}

Kata Kunci:

Proses Pembelajaran, Pandemi Covid-19, Sekolah Dasar

Keywords:

Learning Process, Covid-19

Pandemic, Elementary School

\section{Korespondensi:}

Miptah Parid

Universitas Islam Negeri Sunan

Kalijaga Yogyakarta

Email:

paridmiptah24@gmail.com

\begin{abstract}
ABSTRAK
Penelitian ini bertujuan untuk menjawab beberapa hal serta mengkaji kembali dampak dari pandemi Covid-19 terhadap proses pembelajaran, dalam penelitian ini menggunakan pendekatan deskriptif kualitatif yang berupa penggambaran dari suatu keadaan tertentu dengan menggunakan metode interaktif. Metode interaktif digunakan untuk menelaah isi dari suatu dokumen, tulisan-tulisan dan hasil penelitian yang relevan dengan judul serta objek dalam kajian ini yaitu guru dan siswa. Temuan dalam pembahasan ini menunjukkan bahwa guru dan siswa sangat terdampak dalam proses pembelajaran secara daring. Diharapkan kepada pemerintah untuk mengkaji serta membuat evaluasi proses pembelajaran secara daring karena memiliki beberapa peran yang hilang dalam proses pembelajaran agar generasi sekolah dasar dapat menjadi generasi bermutu walaupun di tengah pandemi Covid-19.
\end{abstract}

\section{ABSTRACT}

This study aims to answer a number of things to review the impact of the Covid-19 pandemic on the learning process, in this study using a qualitative descriptive approach in the form of a description of a particular situation using interactive methods. The interactive method is used to examine the contents of a document, writings, and research results that are relevant to the titles and objects in this study, namely students and teachers. The findings in this discussion indicate that teachers are highly affected in the online learning process and also students take part in getting the effects of these impacts. It is expected that the government review and make an evaluation of the learning process online because it has several roles missing in the learning process so that the elementary school generation can be a quality generation even in the midst of a COVID-19 pandemic.

(C)2021 LPPM STKIP Persada Khatulistiwa Sintang

\section{PENDAHULUAN}

Dunia dihebohkan dengan virus corona atau yang lebih dikenal dengan Covid19, berawal dari negeri Tirai Bambu yaitu China tepatnya di kota Wuhan virus ini berasal, sehingga selisih hari berganti virus ini menyebar keseluruh pelosok dunia, virus Covid-19 hingga saat ini belum pula sirna karena jenis virus ini bertahan lama serta proses penularanyapun belum diketahui secara pasti oleh para ahli di negara manapun hanya dapat menjadi patokan dengan membiasakan pola hidup bersih untuk pencegahannya.

Virus ini membawa gangguan yang amat mengkhawatirkan dan membuat banyak manusia menjadi panik karenanya, dari berbagai aktivitas manusia di dunia dari aktifitas keseharian seperti pekerjaan ataupun 
berbagai aktivitas lainnya sampai proses pembelajaran di tingkat usia dini sampai dengan perkuliahanpun terganggu, sehingga UU RI tentang sistem pendidikan nasional tahun 2003 terkait interaksi tidak tejalankan dengan maksimal (Pane \& Darwis Dasopang, 2017). Banyak negara dan negeri kita tercinta ini pun memutuskan untuk meliburkan sekolah dan perguruan tinggi untuk keputusan dalam menangani virus ini, karena berpandangan bahwa dengan keputusan tersebut dapat memutuskan tali rantai virus Covid-19.

Virus Covid-19 ini berawal pada bulan Desember peralihan tahun ke 2020 pada tanggal 8 Desember 2019 tetapi China melaporkan ke WHO (World Health Organization) pada tanggal 31 Desember 2019 tepat pada tanggal 23 januari 2020 kota Wuhan diisolasi karena diduga sumber kuat sumber virus ini (Rekap Perkembangan Virus Corona Wuhan Dari Waktu Ke Waktu Halaman All - Kompas.Com, n.d). Menularnya Covid-19 membuat dunia sangat resah saat ini termasuk di negera Indonesia, virus ini tergolong baru sehingga banyak pihak yang tidak tahu dan tidak mengerti cara penanggulangan virus tersebut. Terkait dalam hal menyelamatkan sumber daya manusia di Indonesia pemerintah republik Indonesia menerbitkan protokol kesehatan dan protokol ini akan dilaksanakan di seluruh Indonesia yang dipandu secara terpusat oleh Kementrian Kesehatan Republik Indonesia sebagai penangung jawab pada bidang kesehatan.

$$
\text { Pandemi Covid-19 selain }
$$

terganggunya proses pembelajaran juga berdampak pada ekonomi setiap warga negara di Indonesia, karena mereka tidak dapat berjualan untuk memenuhi keberlangsungan hidup, akhirnya berdampak kepada siswa yang orang tuanya berada pada standar ekonomi yang rendah, karena di masa pandemi Covid19 pembelajaran dilakukan secara daring (online), sehingga sangat Membutuhkan jaringan untuk terkoneksi internet, dimana fungsi internet tersebut merupakan dunia maya tempat para pengguna internet berkomunikasi (Yuhelizar, 2008).

Bagi siswa yang tinggal di pelosok dan orang tua yang berada di taraf ekonomi rendah maka belum dapat memenuhi kebutuhan dalam proses pembelajaran anak, serta jaringan di daerahnya tidak mendukung lalu yang terjadi adalah proses pembelajaran anak terganggu contoh misalkan di sekolah dasar yang mana mereka ada yang mempunyai handpone atau laptop ada juga yang belum mempunyainya karena berhubungan dengan dampak ekonomi keluarga, dalam hal pandemi ini terjadi banyak dampak di dalam segi manapun.

Dampak merupakan suatu gejala yang timbul dari suatu akibat sama halnya dengan pengaruh merupakan dorongan atau bujukan dan bersifat membentuk atau merupakan suatu efek (Hugiono \& Poerwantana, 2000). Sebagai pengajar, guru hendaknya memiliki perencanaan (planning) pengajaran yang cukup matang. Perencanaan pengajaran tersebut erat kaitannya dengan berbagai unsur seperti tujuan pengajaran, bahan pengajaran, kegiatan belajar, metode mengajar, dan 
evaluasi. Unsur-unsur tersebut merupakan bagian integral dari keseluruhan tanggung jawab guru dalam proses pembelajaran (Hasyim, 2014). Tetapi dengan adanya pandemi ini pula guru tidak dapat menjalankan peranannya dalam tangung jawab secara penuh karena keterbatasan ruang dan waktu. Selain itu pula dampak yang dirasakan guru yaitu tidak semua mahir menggunakan teknologi internet atau media sosial sebagai sarana pembelajaran (Purwanto et al., 2020).

Berdasarkan hal ini peneliti juga mengamati beberapa berita baik melalui media cetak maupun online serta sosial media dan juga mencari informasi kepada beberapa teman yang sudah menjadi guru di beberapa daerah yang ada di Indonesia dalam hal ini cukup memprihatinkan kepada dunia pendidikan khususnya dalam proses pembelajaran tidak berjalan maksimal di pendidikan Dasar karena beberapa kendala serta hambatan dalam proses pembelajarannya, ada yang mengeluhkan tidak ada jaringan orang tua belum mempunyai ponsel pintar ataupun laptop belum ada dan lain sebagainya sehingga guru menjadi terkedala dalam melaksanakan proses pembelajarannya, dampak yang terjadi pendidikan di Indonesia menjadi terbengkalai anak-anak tidak terdidik secara universal dalam pembelajarannya.

Banyak para peneliti terdahulu yang membahas mengenai proses pembelajaran yang telah dikaji dan digunakan sebagai rujukan awal peneliti. Literatur penelitian proses pembelajaran tersebut antara lain sebagai berikut: pertama, Shafa meneliti tentang karakteristik proses pembelajaran kurikulum 2013(Shafa, 2014); kedua, Kirom meneliti tentang peran guru dan peserta didik dalam proses pembelajaran multikultural(Kirom, 2017); ketiga, Nana tentang dasar-dasar proses belajar (Sudjana, 2013), keempat, Nahar tentang penerapan teori belajar Psikologi behavioristik dalam proses pembelajaram (Nahar, 2016); dan kelima, Rusman tentang belajar dan pembelajaran berorientasi standar proses Pendidikan (Rusman, 2017).

Dari berbagai penelitian tentang proses pembelajaran yang telah dilakukan dalam penelitian sebelumnya, maka penulis dalam penelitian ini membahas mengenai dampak pandemi Covid-19 terhadap proses pembelajaran siswa tingkat sekolah dasar.

Bayangan tentang masa depan anak tidak mungkin muncul dengan sendiri. Paling tidak ada proses yang mengantar bayangan itu kepada mereka.(Ambaryani, 2019) Apabila hal ini tidak menjadi perhatian pemerintah maka akan berdampak hal yang lebih besar kepada peserta didik terutama kepada siswa sekolah dasar yang merupakan cakupan dalam penelitian ini, terkait dengan hal tersebut peneliti ingin meneliti secara mendalam terkait paparan keseluruhan yang telah dijelaskan diatas, peneliti menarik untuk mengkaji tentang dampak dari pandemi Covid-19 ini di sekolah dasar siapa saja yang terkendala terdampak atas pandemi Covid-19 yang melanda negari ini dan juga tanggapan dari beberapa guru yang mengajar di beberapa kota di Indonesia bagaimana tanggapan mereka 
terkait proses pembelajaran secara daring yang mereka lakukan, dalam hal ini peneliti menindak lanjuti penelitian ini dengan konsep judul: Dampak Pendemi Covid-19 Terhadap Proses Pembelajaran Siswa Sekolah Dasar. Semoga dengan berkontribusinya peneliti dalam tulisan ini dapat menjadi perhatian pemerintah untuk generasi emas yang mereka impikan selama ini.

\section{METODE PENELITIAN}

Penelitian ini merupakan penelitian literatur melalui analisis dokumen berupa studi pustaka. Bentuk penelitian ini adalah kualitatif dengan metode deskriptif yang berupa penggambaran dari suatu keadaan atau fenomena tertentu dengan menggunakan metode interaktif. Metode interaktif digunakan untuk menelaah isi dari suatu dokumen, tulisan, atau hasil penelitian yang relevan dengan tulisan ini. Penelitian literatur atau kajian pustaka yang merupakan serangkaian kegiatan yang berkenaan dengan metode pengumpulan data pustaka, membaca dan mencatat serta mengelolah bahan koleksi perpustakaan tanpa memerlukan riset lapangan.(Mestika, 2004) Teknik pengumpulan data dalam penelitian ini adalah analisis isi. Analisis isi yaitu dengan mencatat dokumen atau arsip yang berkaitan erat dengan tujuan penelitian dalam hal ini penulis membagikan google from untuk di isi oleh guru yang ada di beberpa kota di Indonesia. Analisis isi dilakukan dengan membahas dampak terhadap proses pembelajaran di sekolah dasar baik dampak kepada siswa maupun guru dalam menghadapi pandemi Covid-19.

\section{HASIL DAN PEMBAHASAN \\ 1. Coronovirus Disease 2019 (COVID-19)}

Pedoman pencegahan dan pengendalian Covid-19 bagi siswa tingkat sekolah dasar yaitu sebagai berikut: 1) bagi siswa yang memiliki riwayat hidup/tinggal atau berkunjung di lokasi yang tinggi pandemi disarankan supaya karantina diri di dalam rumah selama 14 hari; 2) periksa suhu tubuh dan status kesehatan setiap hari, mengurangi pergi keluar rumah dan menghindari kontak langsung dengan orang lain; 3) gunakan masker secara benar pada saat kontak langsung dengan guru-guru atau pelajar lainya, kurangi ruang lingkup kegiatan; 4) kepala sekolah harus memantau kondisi kesehatan siswanya lebih dekat, jika ada tanda-tanda mencurigakan terkait Covid-19 segera melapor ke pihak yang bertanggungjawab; 5) sekolah-sekolah harus menghindari membuat kegiatan sekala besar, memperkuat/memperhatikan ventilasi dan membersihkan ruanagn kelas, asrama, perpustakaan, pusat kegiatam dan lingkungan sekolah lainya; 6) kepala sekolah dan guru memnagadakan pembelajaran daring dan kelas khusu bagi anak-anak.(NTT, 2020)

\section{Proses Pembelajaran Siswa}

Proses pembelajaran adalah proses yang di dalamnya terdapat kegiatan interaksi antara guru-siswa dan komunikasi timbal balik yang berlangsung dalam situasi edukatif untuk mencapai tujuan belajar (Rustaman, 2001). Di dalam proses pembelajaran, guru dan siswa merupakan dua komponen yang tidak bisa 
dipisahkan. Antara dua komponen tersebut harus terjalin interaksi yang saling menunjang agar hasil belajar siswa dapat tercapai secara optimal seperti yang diharapkan. Menurut pendapan lain pembelajaran dapat diartikan sebagai usaha atau proses belajar mengajar dalam rangka terciptanya proses belajar mengajar yang efektif dan efisien.(Bafadal, 2005)

Efektif adalah perubahan yang membawa pengaruh, makna dan manfaat tertentu. Pembelajaran yang efektif ditandai dengan sifatnya yang menekankan pada pemberdayaan siswa secara aktif. Pembelajaran menekankan pada penguasaan pengetahuan tentang apa yang dikerjakan, tetapi lebih menekankan pada internalisasi, tentang apa yang dikerjakan sehingga tertanam dan berfungsi sebagai muatan nurani dan hayati serta dipraktekkan dalam kehidupan oleh siswa.(Fakhrurrazi, 2018) Serta menyiapkan perangkat tindakan yang dirancang untuk mendukung proses belajar peserta didik, dengan memperhitungkan kejadian-kejadian eksternal yang berperanan terhadap rangkaian kejadian-kejadian internal yang berlangsung di dalam peserta didik.(Suwito, 2016)

Berdasarkan penjelasan diatas maka dapat kita pahami bahwa proses pembelajaran merupakan suatu usaha guru dalam mendidik peserta didiknya dengan melakukan interaksi yang dapat menunjang pengetahuan siswa dengan penyiapan materi serta unsur-unsur dalam manajemen proses pembelajaran agar terciptanya proses yang efektif serta efisien sehingga membuat para peserta didik aktif dalam merespon apa yang diberikan guru.

Pembelajaran dapat dibedakan ke dalam dampak langsung atau dampak instruksional dan dampak tak langsung atau dampak kegiatan pembelajaran yang telah diprogramkan semula. Sedangkan dampak iringan muncul sebagai pengaruh dari terjadi pengalaman lingkungan belajar (Sunhaji, 2014).

Penelitian ini Mengambarkan peranan guru tidak maksimal dalam proses pembelajaran karena pembelajaran secara daring kurang efektif bagi peserta didik di lingkungan sekolah dasar, maka dari hal itu butuh perhatian kemendikbut untuk mengatur mekanisme pembelajaran secara daring yang efektif dan efesien sesuai tingkat sekolah.

\section{Dampak Pandemi Covid-19 Terhadap}

\section{Proses Pembelajaran Siswa Sekolah Dasar}

Coronavirus Disease 2019 (COVID19) telah dinyatakan oleh WHO sebagai pandemic dan Indonesia telah menyatakan wajib Covid-19 sebagai bencana non alam berupa wabah penyakit yang wajib dilakukan upaya penanggulangan sehingga tidak terjadi penyebaran virus Covid-19.(Pemerintah Terbitkan Protokol Isolasi Diri Dan Komunikasi Penanganan Covid-19» Info Infeksi Emerging Kementerian Kesehatan RI, n.d.) Sesuai dengan keputusan Mentri Kesehatan Nomor HK.01.07/Menkes/104/2020 tentang penetapan infeksi novel coronavirus (Infeksi 2019-nCoV) sebagai penyakit yang dapat 
menimbulkan wabah dan upaya penanggulanganya, maka berdampak kepada proses pendidikan khususnya pada pendidikan tingkat sekolah dasar yang menjadikan proses pembelajaran menjadi online atau daring sebagai upaya pencegahan penyebaran covid19 di lingkungan pendidikan tingkat sekolah dasar.

Berdasarkan hasil koesioner yang disebarkan melalui google form kepada guruguru yang berada di beberapa kota di Indonesia yaitu : 1) Nurlatifah Hanum Ritnoga guru kelas 3 SD Muhammadiyah 07 Medan; 2) Hilma Suwaya guru kelas 2 SDN 112143 Rantau Utara; 3) Siti Munawaroh guru kelas 5 MIN Asahan; 4) Dwi Rahmasari Handayani guru kelas 3 SDN 1 surade; dan 5) Annisa Rizkania guru kelas 4 MI Nurul Haq Bandung.

Setelah data terkumpul dari seluruh responden, maka di peroleh hasil analisis mengenai dampak Covid-19 terhadap proses pembelajaran melalui cara daring atau online pada tingkat sekolah dasar yaitu sebagai berikut : 1) dampak positif Covid-19 terhadap proses pembelajaran yang menyebabkan proses pembelajaran melalui cara daring atau online yaitu sebagai berikut: siswa belajar lebih mandiri, siswa lebih dekat dengan keluarga, siswa mendapatkan bimbingan langsung dari orang tua, siswa lebih mengenal keluarga, siswa berkomunikasi dengan orang tua jadi lebih akrab, siswa jadi memahi penggunaan teknolgi pembelajaran online, siswa menjadi lebih kreatif, siswa mendapat perhatian langsung dari orang tua, dan menyadarkan orang tua betapa beratnya tugas guru dalam mengajarkan anaknya; 2) dampak negatif Covid-19 terhadap proses pembelajaran yang menyebabkan proses pembelajaran melalui cara daring atau online yaitu sebagai berikut: siswa yang tidak mempunyai koneksi internet susuah untuk belajar online, guru tidak maksimal dalam berkomunikasi dengan siswa, kuota internet menjadi boros karena terlalu bnayak menggunkan internet, siswa susah mengikuti anjuran guru karena terbatas ruang dan waktu, siswa merasa bosan karena merindukan teman dan gurun serta suasana kelas dan guru terbatasi dalam penyampaian materi.

\section{SIMPULAN}

Berdasarkan penjelasan yang telah dibahas, maka kesimpulan dari penulisan ini adalah sebagai berikut: 1) dampak positif Covid-19 terhadap proses pembelajaran yang menyebabkan proses pembelajaran melalui cara daring atau online yaitu sebagai berikut: siswa belajar lebih mandiri, siswa lebih dekat dengan keluarga, siswa mendapatkan bimbingan langsung dari orang tua, siswa lebih mengenal keluarga, siswa berkomunikasi dengan orang tua jadi lebih akrab, siswa jadi memahi penggunaan teknolgi pembelajaran online, siswa menjadi lebih kreatif, siswa mendapat perhatian langsung dari orang tua, dan menyadarkan orang tua betapa beratnya tugas guru dalam mengajarkan anaknya; 2) dampak negatif Covid-19 terhadap proses pembelajaran yang menyebabkan proses pembelajaran melalui cara daring atau online yaitu sebagai berikut: siswa yang tidak mempunyai koneksi internet susuah untuk 
belajar online, guru tidak maksimal dalam berkomunikasi dengan siswa, kuota internet menjadi boros karena terlalu bnayak menggunkan internet, siswa susah mengikuti anjuran guru karena terbatas ruang dan waktu, siswa merasa bosan karena merindukan teman dan gurun serta suasana kelas dan guru terbatasi dalam penyampaian materi.

\section{DAFTAR RUJUKAN}

Ambaryani. (2019). Mimpi Tentang Masa Depan Dalam Karya Anak-Anak Kubu. Jurnal Raheema, Vol. 5 No. 2, hlm. 155-162.

Bafadal. (2005). Pengelolaan Perpustakaan Sekolah. Jakarta: Bumi Aksara.

Fakhrurrazi, F. (2018). Hakikat Pembelajaran Yang Efektif. Jurnal At-Tafkir, Vol 11 ,No.1, hlm. 85-99.

Hasyim, M. H. M. (2014). Penerapan Fungsi Guru Dalam Proses Pembelajaran. AULADUNA: Jurnal Pendidikan Dasar Islam, vol 1, No. 2, hlm. 265276.

Hugiono, \& Poerwantana. (2000). Pengantar Ilmu Sejarah. Jakarta: Bumi Aksara.

Indonesia, K. K. R. (2013). Pedoman Umum Kesiapan Menghadapi Middle east Respiratory Syndrome-Corona Virus (Mers-CoV).

KBBI. (2016). Kamus Besar Bahasa Indonesia ( KBBI ). In Kementerian Pendidikan dan Budaya.

Kemenkes RI. (2020). Pedoman Pencegahan dan Pengendalian Coronavirus Disease (COVID-19). Germas.

Kirom, A. (2017). Peran Guru Dan Peserta Didik Dalam Proses Pembelajaran Berbasis Multikultural. Al Murabbi.

Mestika. (2004). Metode Penelitian Kepustakaan. Jakarta: Yayasan Obor
Indonesia.

Nahar, N. I. (2016). Penerapan teori belajar behavioristik dalam proses pembelajaran. Nusantara, Jurnal Ilmu Pengetahuan Sosial, vol 1, No. 1, hlm. 64-74.

NTT, F. A. (2020). Panduan Menghadapi Penyakit Virus Corona 2019 Model $R R C$. Komisi Kesehatan Nasional RRC.

Organisasi Kesehatan Dunia - Wikipedia bahasa Indonesia, ensiklopedia bebas.

Pane, A., \& Darwis Dasopang, M. (2017). Belajar Dan Pembelajaran. FITRAH:Jurnal Kajian Ilmu-Ilmu Keislaman, Vol. 3 No. 1, hlm. 333352.

Pemerintah Terbitkan Protokol Isolasi Diri dan Komunikasi Penanganan COVID19» Info Infeksi Emerging Kementerian Kesehatan RI. Diakses April 19, 2020, https://covid19.kemkes.go.id/situasiinfeksi-emerging/info-coronavirus/pemerintah-terbitkan-protokolisolasi-diri-dan-komunikasipenanganan-Covid-19/\#.Xpvrsv0zbIU

Purwanto, A., Pramono, R., Asbari, M., Budi Santoso, P., Mayesti Wijayanti, L., Chi Hyun, C., \& Setyowati Putri, R. (2020). Studi Eksploratif Dampak Pandemi COVID-19 Terhadap Proses Pembelajaran Online di Sekolah Dasar. Jurnal EduPsyCound Vol. 2, No 1, hlm 1-12.

Rekap Perkembangan Virus Corona Wuhan dari Waktu ke Waktu Halaman all Kompas.com.

Rusman. (2017). Belajar \& Pembelajaran: Berorientasi Standar Proses Pendidikan. Jakarta: Raja Grafindo Persada

Rustaman. (2001). Keterampilan Bertanya dalam Pembelajaran IPA. Jakarta: Depdiknas. 
Shafa. (2014). Karakteristik Proses Pembelajaran Kurikulum 2013. Jurnal Dinamika Ilmu.Vol. 14, No. 1, hlm:81-96

Sudjana, N. (2013). Dasar-Dasar Proses Belajar. Bandung: Sinar Algensindo

Sunhaji. (2014). Konsep Manajemen Kelas Dan Implikasinya Dalam Pembelajaran. Jurnal Kependidikan, Vol.2, No.2 hlm. 30-46.

Suwito, A. (2016). Pendekatan Parade Untuk Meningkatkan Aktivitas Dan Hasil Belajar Peserta Didik Tentang Materi Sistem Pemerintahan Melalui Pemanfaatan Media Voucher Pada Kelas Xii Ips 2 Sma Negeri 1 Lasem. Jurnal Civis, Vol.5 No. 2, hlm. 843854.

Yuhelizar. (2008). 10 Jam Menguasai Internet Teknologi dan Aplikasinya. Jakarta: PT Elex Media Komputindo. 